\title{
IDENTIFICATION OF SOME FABA BEAN (Vicia faba L.) GENOTYPES USING MORPHOLOGICAL AND MOLECULAR CHARACTERS

\author{
El-Emam, A. A. M. ${ }^{1}$; E. M. Rabie ${ }^{2}$; Aziza M. Hassanin ${ }^{1}$ and
} \\ M. I. El- Abady ${ }^{1}$ \\ 1- Seed Tech. Res. Dep. Field Crops Res. Institute, A.R.C. \\ 2- Legumes Crops Res.Sec. Field Crops Res. Institute, A. R. C.
}

\begin{abstract}
Field and laboratory experiments were carried out at the Farm of ElGemmeza Agricultural Research Station, Gharbia Governorate and Seed Technology Research Department, ARC, Egypt, during 2010/2011and 2011/2012 seasons to identify and discriminate ten faba bean genotypes using morphological characters and molecular marker. The results revealed that some morphological characters such as pinnul shape, lines density of flag flower, pod color at maturity, testa shape and color were useful to identify some genotypes from each other, while they were not enough for identifying other genotypes. By using Inter-simple sequence repeat (ISSR-PCR) technique, it was possible to determine the genetic diversity and relationships of the ten faba bean genotypes included in this study. A total of 71 amplified bands were generated with five ISSR primers, of which 59 (83.1\%) were polymorphic which represent a relatively high polymorphism level. These results are important in protecting of plant breeders rights and at releasing these genotypes as a new varieties.
\end{abstract}

\section{INTRODUCTION}

The morphological, quantitative and biochemical characters study was designed to find out distinguished characters of faba bean genotypes. Morphological characterization is the first step in the classification and description of any crop germplasm. Nevertheless, the qualitative traits are often used for separating varieties when a limited range of quantitative traits are found in certain group. Furthermore, morphological description is a precondition for the protection and registration of varieties (UPOV 2002). Germplasm evaluation is considered the first step in plant breeding program and it is commonly based on a simultaneous examination of large number of populations for several characters of both agronomic and physiological interest (Pezzotti et. al. 1994).Cultivars within species are normally discriminated by morphological descriptors. Many tools are now available for studying genetic variability among accessions including total seed protein, isozymes and various types of molecular markers. Rehab, Tawdy (2007), identified ten vicia faba varieties based on morphological differences in seed, seedling and adult plant such as days from planting to flowering and maturity, anthocyanin coloration, color of testa, number of pods and 1000 seed weight), in addition to biochemical variability of genomic fingerprinting. Zubair et. al., (2007) evaluated 14 quantitative traits for forty diverse mungbean [Vigna radiata (L.) Wilczek] genotypes, they found that medium to high variance was observed for days to flower initiation, days to flowering, days to maturity, plant height and pods per plant. Meanwhile, small variance was observed for seeds per pod and 100 seed weight. Lalazar (2012) evaluate 
the diversity of phenology and morphology traits such as days from germination to flowering and maturity, flower bed length, flowers number and length, flower pedanlel length and 1000 seed weight in 11 genotypes, he reported that the highest days from germination to flowering was in Potomak and Harvester genotypes and the lowest in Wadekh genotype (31 day). The highest number of pod was in Potomak and Harvester genotypes and the lowest in Saksa b/v 615 and Oltin genotypes. The highest 1000 seed weight was noticed from Potomak genotype and same genotype had the lowest days from germination to maturity (50 day). Mudzana et al. (1995) reported that the morphological characters such as plant height, number of days to 50 per cent flowering, flower length, pod length, number of seeds per pod could be used for variety identification of faba beans. Bonetti et al. (1995) reported that 17 bean cultivars were grouped based on pod length (very short, short, medium, long, very long), maturity (early, medium, late) and time of flowering (early, medium and late). Ashok et al. (2008) grouped seven french bean varieties based on hilum color and seed shape. On the other hand, the most commonly used polymerasechain reaction (PCR)-based marker systems for genetic diversity and relationships in faba bean species are randomly amplified polymorphic DNA (RAPD) (Link et. al., 1995), amplified fragment length polymorphism (AFLP) (Duc et al., 2010) and species specific repeats (SSR) (Zeid et. al., 2009). The main limitations of these methods are low reproducibility of RAPD, high cost of AFLP and the necessity to know the flanking sequences to develop species specific primers for SSR polymorphism (Belaj et. al., 2003; Jabbarzadeh, et. al., 2010). Inter-simple sequence repeat (ISSR-PCR) is aroute that overcomes most of these technical limitations (Chen et. al., 2008). ISSR markers have been widely applied to characterize plant germplasm and to demonstrate its effectiveness in assessments of plant genetic diversity (Galvain et. al., 2003, Pharmawati et. al., 2005 and Bhagyawant and Srivastava 2008).

The purpose of the present study was to identify ten faba bean genotypes by using some morphological traits and describe the genetic diversity of these by using Inter-Simple Sequence Repeats (ISSRs) and classify these genotypes.

\section{MATERIALS AND METHODS}

Field and laboratory experiments were carried out at Gemmeiza Agriculture Research Station, Gharbia Governorate, and Seed Technology Research Department, ARC, Giza during 2010/2011 and 2011/2012 seasons. Seeds of the studied genotypes were received from Legume Research Dep., Field Crops Research Institute, Agricultural Research Center. The experimental design was a Randomized Complete Block design with three replications. Seeds were inoculated and hand planted. Sowing date was $15^{\text {th }}$ November in the first season, while it was $20^{\text {th }}$ November in the second season. All the agronomic practices were conducted as recommended and the studied traits were as follows:- 


\section{Morphological characters}

Qualitative traits were visually recorded using scales reported by IBPGR (1984). These characters included; anthocyanin coloration, leaf size spots on ears, pinnul shape, color of stem, color of flower ground, lines density on flag flower, wing color of flower, pod corner with stem, pod shape, reversal of pod surface, pod color at maturity, pods division on stem, color of testa, color of Hilum, seed shape and testa shape.

\section{Quantitative characters}

These characters included; days from sowing to $50 \%$ flowering of plants with at lest one flower and days from sowing to maturity, stem thickness, time of beginning of flowering, time of maturity, highest of the first pod $(\mathrm{cm})$, number of pinnule/ leaf, branching grassroots, number of flowers/ marble, number of pod at nods, number of seeds/ pod, plat height $(\mathrm{cm})$ and seed index. Collected data for each season were statistically analyzed and the Least Significant Difference (L.S.D.) was used to compare among them (Gomez and Gomez, 1984).

\section{Molecular markers}

\section{Plant material and DNA extraction:}

DNA was extracted from the tissue of young, healthy leaf which was selected from each genotype, using the DNA extraction kit (Quigen Inc., Cat.no.69104, USA). DNA quality was tested using 1\% agarose gel electrophoresis and its concentration was determined spectrophotometrically.

\section{ISSR-PCR analyses}

Five ISSR primers were selected for testing the genetic diversity between these genotypes. Names and sequences of these primers are shown in Table (1). The PCR reaction was carried out in a $25 \mu \mathrm{l}$ volume of a mixture containing $25 \mathrm{ng}$ of genomic DNA, $0.1 \mathrm{mM}$ dNTPs, $2.5 \mathrm{mM} \mathrm{MgCl} 2,1$ unit Taq polymerase, $10 \times$ Taq buffer and $0.6 \mu \mathrm{M}$ primer. DNA amplification was carried out using the thermocycler model PTC 200 (MJ Research, Watertown, MA, USA). The amplification program included a denaturing step at $94{ }^{\circ} \mathrm{C}$ for $5 \mathrm{~min}$, followed by 35 cycles with a denaturing step at $94{ }^{\circ} \mathrm{C}$ for $1 \mathrm{~min}$, an annealing step at $53^{\circ} \mathrm{C}$ for $1 \mathrm{~min}$ and an extension step at $72^{\circ} \mathrm{C}$ for 2 min. After the last cycle, samples were kept at $72{ }^{\circ} \mathrm{C}$ for 5 min.

Gel electrophoresis

Gel electrophoresis was applied according to Sambrook et al. (1989). Agarose (1.2\%) was used for resolving the PCR products. Bands were detected on UV-transilluminator and photographed by Gel documentation 2000, Bio- Rad. Similarity and dendrogram tree was performed using the SPSS program version 10 .

Table (1): Names and sequences of the five primers used for ISSR-PCR analyses.

\begin{tabular}{|c|l|}
\hline Primer name & \multicolumn{1}{c|}{ Sequence } \\
\hline SH6 & $5^{\prime}$ CGCGATAGATAGATAGATA 3 \\
\hline SH7 & $5^{\prime}$ GACGATAGATAGATAGATA 3 \\
\hline SH8 & $5^{\prime}$ AGACAGACAGACAGACGC 3/ \\
\hline SH9 & 5 GATAGATAGATAGATAGC 3/ \\
\hline SH10 & 5/ GACAGACAGACAGACAAT 3/ \\
\hline
\end{tabular}




\section{RESULTS AND DISCUSSION}

Some morphological characters of the different faba bean genotypes are presented in Table (2). The genotypes $\left(\mathrm{G}_{429} \times \mathrm{G}_{40}\right)$ and $\left(\mathrm{H}_{8} \times \mathrm{G}_{461}\right)$ identified with anthocyanin coloration mixture and mixture violet, respectively while in the other faba bean genotypes it was absent, the genotypes $\left(G_{B l a n k a} \times G_{2}\right)$ and $\left(\mathrm{H}_{10} \times \mathrm{G}_{461}\right)$ have weak violet.

Table (2): Some morphological characters of faba bean genotypes (combined dataof 2010/ 2011 and 2011/2012 growing seasons).

\begin{tabular}{|c|c|c|c|c|c|c|}
\hline Genotypes & $\begin{array}{c}\text { Anthocyanin } \\
\text { coloration }\end{array}$ & $\begin{array}{c}\text { Leaf } \\
\text { size }\end{array}$ & $\begin{array}{c}\text { Spots on } \\
\text { ears }\end{array}$ & $\begin{array}{c}\text { Pinnul } \\
\text { shape }\end{array}$ & $\begin{array}{c}\text { Color of } \\
\text { stem }\end{array}$ & $\begin{array}{c}\text { Color of } \\
\text { flower } \\
\text { ground }\end{array}$ \\
\hline $\mathrm{G}_{461} \times \mathrm{G}$. Blanka & Absent & Large & Present & $\begin{array}{c}\text { Semi } \\
\text { Flat }\end{array}$ & Light brown Light brown \\
\hline T.W. $\times$ G.Blanka & Absent & Medium & Absent & Round & Brown & Light brown \\
\hline $\mathrm{G}_{716} \times \mathrm{G}_{402}$ & Absent & Small & Present & Round & Brown & Light brown \\
\hline $\mathrm{G}_{461} \times \mathrm{G}_{402}$ & Absent & Medium & Present & Round & Light brown & White \\
\hline G.Blanka $\times \mathrm{G}_{2}$ & $\begin{array}{l}\text { Weak } \\
\text { Violet }\end{array}$ & Small & Absent & Narrow & Brown & White \\
\hline $\mathrm{G}_{429} \times \mathrm{G}_{2}$ & Absent & Medium & Present & Narrow & Light brown & White \\
\hline $\mathrm{G}_{429} \times \mathrm{G}_{40}$ & Mixture & small & Present & Narrow & Brown & White \\
\hline $\mathrm{H}_{8} \times \mathrm{G}_{461}$ & Medium violet & Large & Absent & Narrow & Very light & White \\
brown & \\
\hline $\mathrm{H}_{10} \times \mathrm{G}_{461}$ & $\begin{array}{l}\text { Weak } \\
\text { Violet }\end{array}$ & Medium & Present & Round & Light brown & White \\
\hline T.W. $\mathrm{G}_{461} \times \mathrm{Egypt}_{1}$ & Absent & Large & Present & Round & Dark brown & White \\
\hline
\end{tabular}

Leaf size can divide the tested genotypes into three groups; small $\left(G_{716} \times G_{402}, G_{\text {Blanka }} \times G_{2}\right.$, and $\left.G_{429} \times G_{40}\right)$, medium (T.W.x $G_{\text {Blanka }}, G_{461} \times G_{402}$ and $\left.\mathrm{H}_{10} \times \mathrm{G}_{461}\right)$ and large $\left(\mathrm{G}_{461} \times \mathrm{G}_{\text {Blanka }}, \mathrm{H}_{8} \times \mathrm{G}_{461}\right.$, and (T.W.X $\left.\mathrm{G}_{461}\right) \times$ Egypt1). Regarding Spots on ears, they were present in the genotypes $\left(G_{461} \times G_{\text {Blanka }}\right.$, $\mathrm{G}_{716} \times \mathrm{G}_{402}, \mathrm{G}_{461} \times \mathrm{G}_{402}, \mathrm{G}_{429} \times \mathrm{G}_{2}, \mathrm{G}_{429} \times \mathrm{G}_{40}, \mathrm{H}_{10} \times \mathrm{G}_{461}$ and (T.W.x $\left.\mathrm{G}_{461}\right) \times E_{\text {gypt }}$ and absent in the genotypes (T.W.x $G_{\text {Blanka }}, G_{\text {Blanka }} \times G_{2}$, and $H_{8} \times G_{461}$ ). The genotype $\left(\mathrm{G}_{461} \times \mathrm{G}_{\text {Blanka }}\right)$ identified with pinnul shape (semi flat). The genotypes $\left(\mathrm{H}_{8} \times \mathrm{G}_{461}\right.$ and (T.W.X $\left.\mathrm{G}_{461}\right) \times$ Egypt $_{1}$ ) were identified with color of stem (very light brown and dark brown), respectively. Color of flower ground characters divided faba bean genotypes under studied into two classes, the first class, concluded the genotypes $\left(G_{461} \times G_{402}, G_{461} \times G_{\text {Blanka }}\right.$, T.W.x $G_{B l a n k a}$ and $G_{716} \times G_{402}$ ) light brown. Meanwhile, the second class (white) was concluded the genotypes $\left(G_{461} \times G_{402}, G_{\text {Blanka }} \times G_{2}, G_{429} \times G_{2}, G_{429} \times G_{40}, H_{8} \times G_{461}, H_{10} \times G_{461}\right.$ and (T.W.XG $\left.\left.G_{461}\right) \times E_{g y p t}\right)$. These results are in agreement with Rehab, Towdy (2007) she reported that, anthocyanin coloration was absent in Sahel 1 while in the other varieties was present, Intensity of anthocyanine coloration was medium in Mesr 1 but was slight for the rest of varieties and showed that, 
Mesr 1 and Nubaria 1 varieties were short in leaflet size while the other varieties were medium.

Data in Table (3), show some morphological characters of different faba bean genotypes included in this study. The genotype $\left(\mathrm{G}_{461} \times \mathrm{G}_{\text {Blanka }}\right)$ identify with lines density on flag flower (dense). Regarding wing color of flower, all faba bean genotypes were black spot. Pod corner with stem can divide the tested genotypes into two groups; the genotypes $\left(\mathrm{G}_{461} \times \mathrm{G}_{\text {Blanka, }}\right.$, $G_{429} \times G_{2}, G_{429} \times G_{40}, H_{8} \times G_{461}$ and (T.W.x $\left.G_{461}\right) \times E$ gypt 1 ) were mixture and the genotypes (T.W.x $G_{\text {Blanka }}, G_{716} \times G_{402}, G_{461} \times G_{402}, G_{\text {Blanka }} \times G_{2}$ and $H_{10} \times G_{461}$ ) were existing. The genotypes under study divided into three class according to pod shape the genotypes $\left(G_{461} \times G_{\text {Blanka }}\right.$, T.W. $\times G_{\text {Blanka }}, G_{716} \times G_{402}, G_{429} \times G_{2}, G_{429} \times G_{40}$ and $\left.\mathrm{H}_{8} \times \mathrm{G}_{461}\right)$ have semi-cylindrical while, the genotypes $\left(\mathrm{G}_{461} \times \mathrm{G}_{402}\right.$ and (T.W.X $\left.G_{461}\right) \times$ Egypt $\left._{1}\right)$ were narrow extrovert and the genotypes $\left(G_{\text {Blanka }} \times G_{2}\right.$ and $\mathrm{H}_{10} \times \mathrm{G}_{461}$ ) were extrovert non narrow under pod shape. Regarding reversal of pod surface, the genotypes $\left(\mathrm{G}_{461} \times \mathrm{G}_{\text {Blanka }}, \mathrm{G}_{429} \times \mathrm{G}_{2}, \mathrm{G}_{429} \times \mathrm{G}_{40}\right.$ and (T.W. $\left.\times G_{461}\right) \times E_{\text {Egypt }}$ ) have shiny surface and the genotypes (T.W.X $G_{\text {Blanka }}$, $G_{716} \times G_{402}, G_{461} \times G_{402}, G_{\text {Blanka }} \times G_{2}, H_{8} \times G_{461}$ and $H_{10} \times G_{461}$ ) have matted pod surface. The genotypes $\left(\mathrm{G}_{461} \times \mathrm{G}_{\text {Blanka }}, \mathrm{G}_{429} \times \mathrm{G}_{2}, \mathrm{G}_{429} \times \mathrm{G}_{40}, \mathrm{H}_{8} \times \mathrm{G}_{461}\right.$ and (T.W. $\left.\times G_{461}\right) \times$ Egypt $_{1}$ ) can identified with pod color at maturity Dark black, Black, Mixed, White yellow and White brown respectively, while other genotypes were brown.

Table (3): Some morphological characters of faba bean genotypes (combined data of 2010/ 2011 and 2011/2012 growing seasons).

\begin{tabular}{|c|c|c|c|c|c|c|}
\hline Genotypes & $\begin{array}{l}\text { Lines } \\
\text { density } \\
\text { on flag } \\
\text { flower }\end{array}$ & $\begin{array}{l}\text { Wing color } \\
\text { of flower }\end{array}$ & $\begin{array}{l}\text { Pod corner } \\
\text { with stem }\end{array}$ & $\begin{array}{l}\text { Pod } \\
\text { shape }\end{array}$ & $\begin{array}{c}\text { Reversal } \\
\text { of pod } \\
\text { surface }\end{array}$ & $\begin{array}{l}\text { Pod color } \\
\text { at maturity }\end{array}$ \\
\hline $\mathrm{G}_{461} \times \mathrm{G}$.Blanka & Dense & $\begin{array}{l}\text { Black } \\
\text { spot }\end{array}$ & Mixture & $\begin{array}{c}\text { Semi- } \\
\text { cylindrical }\end{array}$ & Shiny & Dark black \\
\hline T.W.xG.Blanka & Medium & $\begin{array}{l}\text { Black } \\
\text { spot }\end{array}$ & Existing & $\begin{array}{c}\text { Semi- } \\
\text { cylindrical }\end{array}$ & Matted & Brown \\
\hline $\mathrm{G}_{716} \times \mathrm{G}_{402}$ & Slight & $\begin{array}{l}\text { Black } \\
\text { spot }\end{array}$ & Existing & $\begin{array}{c}\text { Semi- } \\
\text { cylindrical }\end{array}$ & Matted & Brown \\
\hline $\mathrm{G}_{461} \times \mathrm{G}_{402}$ & Slight & $\begin{array}{c}\text { Black } \\
\text { spot }\end{array}$ & Existing & $\begin{array}{l}\text { Narrow } \\
\text { extrovert }\end{array}$ & Matted & Brown \\
\hline G.BlankaxG ${ }_{2}$ & Slight & $\begin{array}{l}\text { Black } \\
\text { spot }\end{array}$ & Existing & $\begin{array}{c}\text { Extrovert non } \\
\text { narrow }\end{array}$ & Matted & Brown \\
\hline $\mathrm{G}_{429} \times \mathrm{G}_{2}$ & Medium & $\begin{array}{l}\text { Black } \\
\text { spot }\end{array}$ & Mixture & $\begin{array}{c}\text { Semi- } \\
\text { cylindrical }\end{array}$ & Shiny & Black \\
\hline $\mathrm{G}_{429} \times \mathrm{G}_{40}$ & Slight & $\begin{array}{l}\text { Black } \\
\text { spot }\end{array}$ & Mixture & $\begin{array}{c}\text { Semi- } \\
\text { cylindrical }\end{array}$ & Shiny & Mixed \\
\hline $\mathrm{H}_{8} \times \mathrm{G}_{461}$ & Medium & $\begin{array}{l}\text { Black } \\
\text { spot }\end{array}$ & Mixture & $\begin{array}{c}\text { Semi- } \\
\text { cylindrical }\end{array}$ & Matted & $\begin{array}{l}\text { White } \\
\text { yellow }\end{array}$ \\
\hline $\mathrm{H}_{10} \times \mathrm{G}_{461}$ & Medium & $\begin{array}{l}\text { Black } \\
\text { spot }\end{array}$ & Existing & $\begin{array}{c}\text { Extrovert non } \\
\text { narrow }\end{array}$ & Matted & Brown \\
\hline T.W.G ${ }_{461} \times E_{g y p t}$ & Slight & $\begin{array}{l}\text { Black } \\
\text { spot }\end{array}$ & Mixture & $\begin{array}{c}\text { Narrow } \\
\text { extrovert }\end{array}$ & Shiny & $\begin{array}{l}\text { White } \\
\text { brown }\end{array}$ \\
\hline
\end{tabular}


Also some morphological characters of the studied faba bean genotypes are given in Table (4). It is clear that, pods division on stem divided the genotypes under studied into two gropes, the genotypes $\left(G_{461} \times G_{\text {Blanka }}\right.$, T.W. $\times G_{\text {Blanka }}, G_{716} \times G_{402}$ and $\left.G_{461} \times G_{402}\right)$ were both sides of meanwhile, the other genotypes were homogeneous. The genotypes (T.W.X $G_{\text {Blanka }}$ and $H_{10} \times G_{461}$ ) identified with color of testa (White yellow and yellow, respectively). Color of hilum of all genotypes under study was black. Regarding seed shape, the genotypes $\left(G_{461} \times G_{\text {Blanka }}, T . W . \times G_{\text {Blanka }}, G_{716} \times G_{402}\right.$, $G_{\text {Blanka }} \times G_{2}, H_{8} \times G_{461}, H_{10} \times G_{461}$ and (T.W. $\left.\left.\times G_{461}\right) \times E g y p t_{1}\right)$ have extrovert and the genotypes $\left(G_{461} \times G_{402}, G_{429} \times G_{2}\right.$ and $\left.G_{429} \times G_{40}\right)$ have mixture shape. The genotype $\left(G_{429} \times G_{40}\right)$ identity with testa shape (small patches) while, the other genotypes were fate. These results consent with Rehab tawdy (2007), she found that color of testa was beige in all the varieties of faba bean under studies except for G.717 which was semi beige green.

Table (4): Some morphological characters of faba bean genotypes (combined data of 2010/2011 and 2011/2012 growing seasons).

\begin{tabular}{|c|c|c|c|c|c|}
\hline Characters & $\begin{array}{c}\text { Pods division on } \\
\text { stem }\end{array}$ & Color of testa & $\begin{array}{l}\text { Color of } \\
\text { Hilum }\end{array}$ & Seed shape & $\begin{array}{l}\text { Testa } \\
\text { shape }\end{array}$ \\
\hline $\mathrm{G}_{461} \times \mathrm{G}$. Blanka & Both sides of & Dark green & Black & Extrovert & Fate \\
\hline T.W. x G.Blanka & Both sides of & White yellow & Black & Extrovert & Fate \\
\hline $\mathrm{G}_{716} \times \mathrm{G}_{402}$ & Both sides of & Wight green & Black & Extrovert & Fate \\
\hline $\mathrm{G}_{461} \times \mathrm{G}_{402}$ & Both sides of & Mixed & Black & Mixture & Fate \\
\hline G.Blanka x $\mathrm{G}_{2}$ & Homogeneous & Wight brown & Black & Extrovert & Fate \\
\hline $\mathrm{G}_{429} \times \mathrm{G}_{2}$ & Homogeneous & Wight brown & Black & Mixture & Fate \\
\hline $\mathrm{G}_{429} \times \mathrm{G}_{40}$ & Homogeneous & Mixed & Black & Mixture & $\begin{array}{l}\text { small } \\
\text { patches }\end{array}$ \\
\hline $\mathrm{H}_{8} \times \mathrm{G}_{461}$ & Homogeneous & Wight brown & Black & Extrovert & Fate \\
\hline $\mathrm{H}_{10} \times \mathrm{G}_{461}$ & Homogeneous & Yellow & Black & Extrovert & Fate \\
\hline T.W.G.G ${ }_{461} \times$ Egypt $_{1}$ & Homogeneous & Dark green & Black & Extrovert & Fate \\
\hline
\end{tabular}

Combined data of the quantitative characters of the studied faba bean genotypes are presented in Tables (5 and 6 ). It is clear that, two characters namely height of the first nod and time of beginning of flowering were to some exent effective tools to differentiate between genotypes. Whereas as studied characters were almost similar. The genotype $\left(\mathrm{H}_{8} \times \mathrm{G}_{461}\right)$ gave the highest stem thickness $(0.9 \mathrm{~cm})$ and seed index $(89.5 \mathrm{gm})$. The genotype $\left(\mathrm{G}_{429} \times \mathrm{G}_{40}\right)$ recorded maximum of the first nod $(31.1 \mathrm{~cm})$ while, the genotype $\left(\mathrm{H}_{8} \times \mathrm{G}_{461}\right)$ recorded the lowest height of the first nod $(24.5 \mathrm{~cm})$. The genotype $\left(\mathrm{G}_{429} \mathrm{X}\right.$ $G_{2}$ ) recorded the tallest plant height $(102.5 \mathrm{Cm})$ on the other hand, the genotype $\left(G_{429} \times G_{40}\right)$ recorded the shortest plant height $(96.0 \mathrm{~cm})$. Tallest pod length was noticed by the genotype (G.Blanka $\times \mathrm{G}_{2}$ ) $9.9 \mathrm{~cm}$ while, 
shortest pod length was noticed by $\left(\mathrm{G}_{461} \times \mathrm{G}\right.$.Blanka). Concerning time of beginning of flowering and maturity the genotype (T.W.G ${ }_{461} \times E$ gypt $_{1}$ ) was the latest among all the genotypes (55 and 156 days from begging planting) respectively, while the genotype $\left(\mathrm{H}_{10} \times \mathrm{G}_{461}\right)$ was the earliest for beginning of flowering and maturity 46 and 152 days from begging planting, respectively comparing with the other genotypes. The genotypes (G.Blanka $\times G_{2}$ and $H_{10}$ $x G_{461}$ ) recorded highest No. of pinnule/ leaf (5 pinnule) but, the genotype $\left(G_{461} \times G_{402}\right)$ have little No. of flowers/ marble (3 flowers) comparing with the other genotypes. No. of seeds/ pod was (4 seeds) at $\left(G_{429} \times G_{40}\right.$ and T.W. $G_{461} \times E$ gypt $\left._{1}\right)$ genotypes, while it was $(3$ seeds) at all the other genotypes. Similar results were in agreement with Ibrahim (2010) and Al Barri and Munqez (2013), they revealed that VF-14, VF-10 and VF-12 lines significantly longer days to flowering and differed from all the other genotypes, VF-8, VF-12 and VF-13 lines were significantly the tallest plants while, VF-6 and VF-7 were the shortest, VF-11 line showed the lowest average of pod height and VF-19 gave the highest value, VF-4 and VF-10 lines showed the highest pod length, while VF-2 genotype gave the lowest pod length, VF-10 line significantly had the highest average seed number per pod while VF-7 and VF-19 significantly showed the lowest average seed number per pod and VF-4 genotype gave significantly the highest 100-seed weight while, VF-17 and VF-2 gave the lowest 100-seed weight.

Table (5): Some quantitative characters of faba bean genotypes (combined data of 2010/2011 and 2011/2012).

\begin{tabular}{|c|c|c|c|c|c|}
\hline$\overbrace{\text { Genotypes }}^{\text {Characters }}$ & $\begin{array}{l}\text { Stem } \\
\text { thickness } \\
\quad(\mathrm{cm})\end{array}$ & $\begin{array}{l}\text { Height of } \\
\text { the first } \\
\text { nods }(\mathrm{cm})\end{array}$ & $\begin{array}{l}\text { Time of } \\
\text { beginning of } \\
\text { flowering }\end{array}$ & $\begin{array}{l}\text { Time of } \\
\text { maturity }\end{array}$ & $\begin{array}{c}\text { No. of } \\
\text { pinnule/ } \\
\text { leaf }\end{array}$ \\
\hline $\mathrm{G}_{461} \times \mathrm{G}$.Blanka & 0.8 & 26.5 & 48 & 154 & 4 \\
\hline T.W.xG.Blanka & 0.8 & 29.0 & 47 & 154 & 4 \\
\hline $\mathrm{G}_{716} \times \mathrm{G}_{402}$ & 0.7 & 25.5 & 49 & 155 & 4 \\
\hline $\mathrm{G}_{461} \times \mathrm{G}_{402}$ & 0.8 & 26.6 & 48 & 153 & 4 \\
\hline G.Blanka $\times \mathrm{G}_{2}$ & 0.8 & 29.4 & 50 & 154 & 5 \\
\hline $\mathrm{G}_{429} \times \mathrm{G}_{2}$ & 0.8 & 26.9 & 47 & 153 & 4 \\
\hline $\mathrm{G}_{429} \times \mathrm{G}_{40}$ & 0.8 & 31.1 & 47 & 153 & 4 \\
\hline $\mathrm{H}_{8} \times \mathrm{G}_{461}$ & 0.9 & 24.5 & 50 & 153 & 4 \\
\hline $\mathrm{H}_{10} \times \mathrm{G}_{461}$ & 0.8 & 26.6 & 46 & 152 & 5 \\
\hline T.W.G.G ${ }_{461} \times$ Egypt $_{1}$ & 0.7 & 29.1 & 55 & 156 & 4 \\
\hline L.S.D. at $5 \%$ & 0.1 & 2.7 & 0.95 & 1.45 & 1.0 \\
\hline
\end{tabular}


Table (6): Some quantitative characters of faba bean genotypes (combined data of 2010/2011 and 2011/2012).

\begin{tabular}{|l|c|c|c|c|c|c|}
\hline Characters & $\begin{array}{c}\text { No. of } \\
\text { flowers/ } \\
\text { marble }\end{array}$ & $\begin{array}{c}\text { No. of } \\
\text { pods at } \\
\text { nods }\end{array}$ & $\begin{array}{c}\text { No. of } \\
\text { seeds/ } \\
\text { pod }\end{array}$ & $\begin{array}{c}\text { Pod length } \\
\text { (cm) }\end{array}$ & $\begin{array}{c}\text { Plant } \\
\text { height } \\
\text { (cm) }\end{array}$ & $\begin{array}{c}\text { Seed } \\
\text { index } \\
\text { (gm) }\end{array}$ \\
\hline $\mathrm{G}_{461} \times \mathrm{g}_{\text {.Blanka }}$ & 4 & 2 & 3 & 8.6 & 100.3 & 83.8 \\
\hline T.W.xG.Blanka & 4 & 2 & 3 & 9.4 & 99.6 & 87.5 \\
\hline $\mathrm{G}_{716} \times \mathrm{G}_{402}$ & 4 & 1 & 3 & 9.2 & 98.6 & 79.5 \\
\hline $\mathrm{G}_{461} \times \mathrm{G}_{402}$ & 3 & 2 & 3 & 9.1 & 102.0 & 87.2 \\
\hline $\mathrm{G}_{\text {Blanka }} \times \mathrm{G}_{2}$ & 5 & 2 & 3 & 9.9 & 96.8 & 83.6 \\
\hline $\mathrm{G}_{429} \times \mathrm{G}_{2}$ & 4 & 1 & 3 & 9.0 & 102.5 & 83.8 \\
\hline $\mathrm{G}_{429} \times \mathrm{G}_{40}$ & 5 & 1 & 4 & 9.5 & 96.0 & 82.3 \\
\hline $\mathrm{H}_{8} \times \mathrm{G}_{461}$ & 5 & 2 & 3 & 8.9 & 101.5 & 89.5 \\
\hline $\mathrm{H}_{10} \times \mathrm{G}_{461}$ & 5 & 2 & 3 & 9.0 & 98.0 & 87.7 \\
\hline T.W.G & 4 & 1 & 4 & 8.9 & 96.3 & 85.2 \\
\hline L.S.D. at 5\% & 1.0 & 1.0 & 1.0 & 0.6 & 4.7 & 1.9 \\
\hline
\end{tabular}

\section{Molecular marker}

In the present study, five selected primers of ISSR were used to differentiate between the ten faba bean genotypes (Figure 1). Inter-Simple Sequence Repeat (ISSR) technique yield more polymorphisms than other molecular techniques. The five primers amplified different numbers of bands and revealed various levels of polymorphism. A total of 71 ISSR loci were observed and $59(83.1 \%)$ of them were polymorphic. these primers yielded $14,11,18,14$ and 14 bands, respectively (Table 7 ). The percentage of polymorphism was $92.9 \%, 90.9 \%, 72.2 \%, 85.7 \%$ and $78.6 \%$, respectively. The primer $\mathrm{SH} 8$ yielded the largest number of bands (18 band) while, primer SH7 had fewer number of bands. Among all the ISSR loci observed, 11 were unique. The highest number of unique band can observed in primer $\mathrm{SH} 8$ which produced four markers. While, the lowest number can observed in primer $\mathrm{SH} 7$ and $\mathrm{SH} 10$ which produced one marker. The ISSR primer method is reported to produce more complex marker (Parsons et. al., 1997 and Chowdhury et. al., 2002), which is advantageous when differentiating closely related cultivars.

Table (7): Levels of polymorphism and unique genotypes specific bands for ten faba bean genotypes by five ISSR primers.

\begin{tabular}{|c|c|c|c|c|c|c|}
\hline \multirow{2}{*}{ Primer } & \multirow{2}{*}{$\begin{array}{l}\text { Total } \\
\text { bands }\end{array}$} & \multirow{2}{*}{$\begin{array}{l}\text { Polymorphic } \\
\text { bands }\end{array}$} & \multirow{2}{*}{$\begin{array}{l}\text { Monomorp } \\
\text { hic bands }\end{array}$} & \multirow{2}{*}{$\begin{array}{c}\text { Polymorphism } \\
\%\end{array}$} & \multicolumn{2}{|c|}{ Unique bands } \\
\hline & & & & & Genotypes & Ms (bp) \\
\hline $\mathrm{SH} 6$ & 14 & 13 & 1 & 92.9 & $\begin{array}{l}3 \\
5 \\
9\end{array}$ & $\begin{array}{l}938 \\
341 \\
228\end{array}$ \\
\hline $\mathrm{SH} 7$ & 11 & 10 & 1 & 90.9 & 3 & 800 \\
\hline $\mathrm{SH} 8$ & 18 & 13 & 5 & 72.7 & $\begin{array}{l}9 \\
8 \\
3 \\
6\end{array}$ & $\begin{array}{c}1493 \\
927 \\
644 \\
266\end{array}$ \\
\hline $\mathrm{SH} 9$ & 14 & 12 & 2 & 85.7 & $\begin{array}{l}5 \\
4\end{array}$ & $\begin{array}{l}681 \\
556\end{array}$ \\
\hline $\mathrm{SH} 10$ & 14 & 11 & 3 & 78.6 & 2 & 729 \\
\hline Total & 71 & 59 & 12 & 83.1 & & \\
\hline
\end{tabular}


SH6

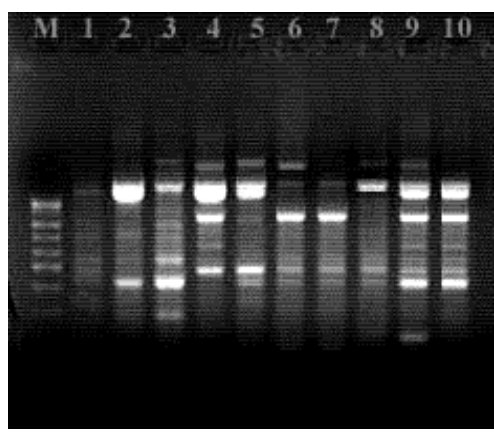

SH8

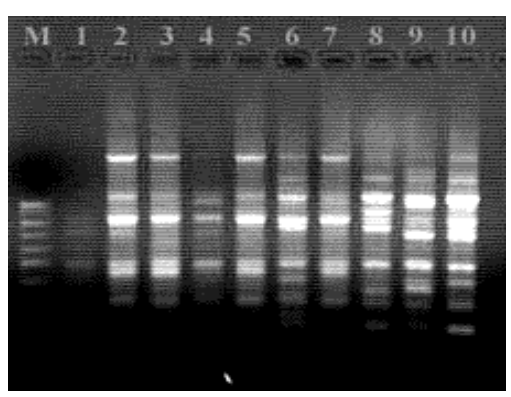

SH7

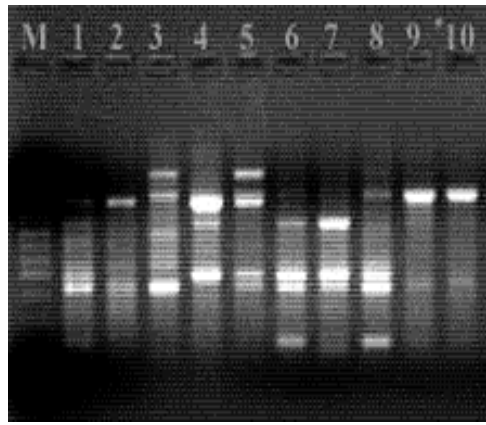

SH9

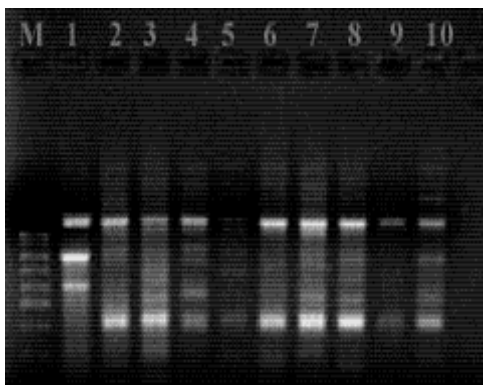

\section{SH10}

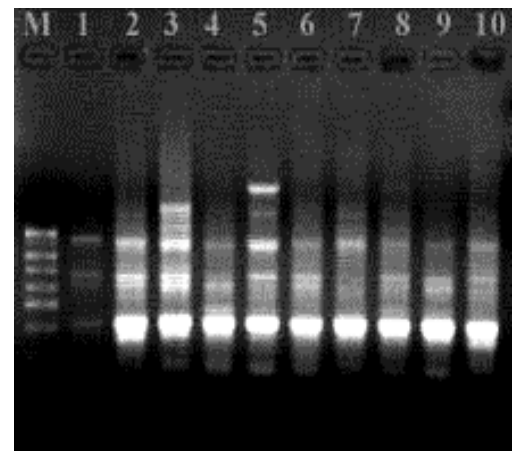

Figure (1): ISSR fingerprinting of ten faba bean genotypes, Lines from left to right: $M=$ Marker, $G_{461} \times G_{\text {Blanka, }}$ T.W.XG $G_{\text {Blanka, }}, G_{716} \times G_{402}$, $\mathrm{G}_{461} \times \mathrm{G}_{402}, \mathrm{G}_{\text {Blanka }} \times \mathrm{G}_{2}, \mathrm{G}_{429} \times \mathrm{G}_{2}, \mathrm{G}_{429} \times \mathrm{G}_{40}, \mathrm{H}_{8} \times \mathrm{G}_{461}, \mathrm{H}_{10} \times \mathrm{G}_{461}$ and (T.W.X $\left.G_{461}\right) \times$ Egypt $_{1}$.

\section{Genetic diversity}

Standard genetic distances could be estimated between all the genotypes showed in Table (8). The genetic similarity ranged from $81 \%$ to $53 \%$ with an average of $67 \%$. The closest distance was found between the genotypes $\left(\mathrm{G}_{429} \times \mathrm{G}_{2}\right)$ and (T.W.x $\left.\mathrm{G}_{461}\right) \times$ Egypt 1 ) and also between $\left(\mathrm{H}_{10} \times \mathrm{G}_{461}\right)$ 


\section{El-Emam, A. A. M. et al.}

and (T.W.X $\left.G_{461}\right) \times$ Egypt 1 (81\%), while the longest was between the genotypes $\left(\mathrm{G}_{716} \times \mathrm{G}_{402}\right)$ and $\left(\mathrm{H}_{10} \times \mathrm{G}_{461}(53 \%)\right.$. The results of clustering genetic distance using the unweighted pair group method separated genotypes to two main clusters with many subclusters, where, the genotype $1\left(\mathrm{G}_{461} \times \mathrm{G}_{\text {Blanka }}\right)$ was in a separate subcluster, while, the other genotypes were in the second subcluster (Figure 2). Salem et. al., (2011) subjected Thirty-four faba bean (Vicia faba L.) to molecular diversity assessment using 12 inter-simple sequence repeat primers and found that there is a high genetic variability related to collection sites and it should be utilised in faba bean improvement. Also, Abdel-Razzak et. al., (2012) clarified that ISSR markers and protein analysis were helpful to recognize genetic variation among faba bean cultivars.

Table (8): Similarity matrix among ten faba bean genotypes based on ISSR analysis.

\begin{tabular}{|c|c|c|c|c|c|c|c|c|c|}
\hline Genotypes & $\begin{array}{c}\mathbf{G}_{461} \mathbf{X} \\
\mathbf{G}_{\text {Blankk }}\end{array}$ & $\begin{array}{l}\text { T.W.X } \\
\text { G }_{\text {Blanka }}\end{array}$ & $\begin{array}{c}\mathbf{G}_{716} \mathbf{X} \\
\mathbf{G}_{402}\end{array}$ & $\begin{array}{c}\mathbf{G}_{461} \mathbf{X} \\
\mathrm{G}_{402}\end{array}$ & $\begin{array}{c}\mathbf{G}_{\text {Blanka }} X \\
\mathrm{G}_{2}\end{array}$ & $\begin{array}{c}\mathbf{G}_{429} \mathrm{x} \\
\mathrm{G}_{2}\end{array}$ & $\begin{array}{c}\mathbf{G}_{429} \mathbf{X} \\
\mathbf{G}_{40}\end{array}$ & $\begin{array}{l}\mathrm{H}_{8} \mathbf{X} \\
\mathrm{G}_{461}\end{array}$ & $\begin{array}{l}\mathbf{H}_{10} \mathrm{X} \\
\mathbf{G}_{461}\end{array}$ \\
\hline \multicolumn{10}{|l|}{$\mathrm{G}_{461} \times \mathrm{G}_{\text {Blanka }}$} \\
\hline T.W.x G Glanka & 0.64 & & & & & & & & \\
\hline $\mathrm{G}_{716} \times \mathrm{G}_{402}$ & 0.64 & 0.74 & & & & & & & \\
\hline $\mathrm{G}_{461} \times \mathrm{G}_{402}$ & 0.63 & 0.60 & 0.61 & & & & & & \\
\hline $\mathrm{G}_{\text {Blanka }} \times \mathrm{G}_{2}$ & 0.56 & 0.69 & 0.63 & 0.62 & & & & & \\
\hline $\mathrm{G}_{429} \times \mathrm{G}_{2}$ & 0.70 & 0.64 & 0.61 & 0.71 & 0.72 & & & & \\
\hline $\mathrm{G}_{429} \times \mathrm{G}_{40}$ & 0.69 & 0.74 & 0.73 & 0.70 & 0.68 & 0.77 & & & \\
\hline $\mathrm{H}_{8} \times \mathrm{G}_{461}$ & 0.65 & 0.68 & 0.72 & 0.69 & 0.69 & 0.78 & 0.79 & & \\
\hline $\mathrm{H}_{10} \times \mathrm{G}_{461}$ & 0.60 & 0.61 & 0.53 & 0.69 & 0.66 & 0.73 & 0.60 & 0.68 & \\
\hline$\left(T . W . x G_{461}\right) \times$ Egypt $_{1}$ & 0.66 & 0.74 & 0.61 & 0.70 & 0.68 & 0.81 & 0.76 & 0.72 & 0.81 \\
\hline
\end{tabular}

Rescaled Distance Cluster Combine

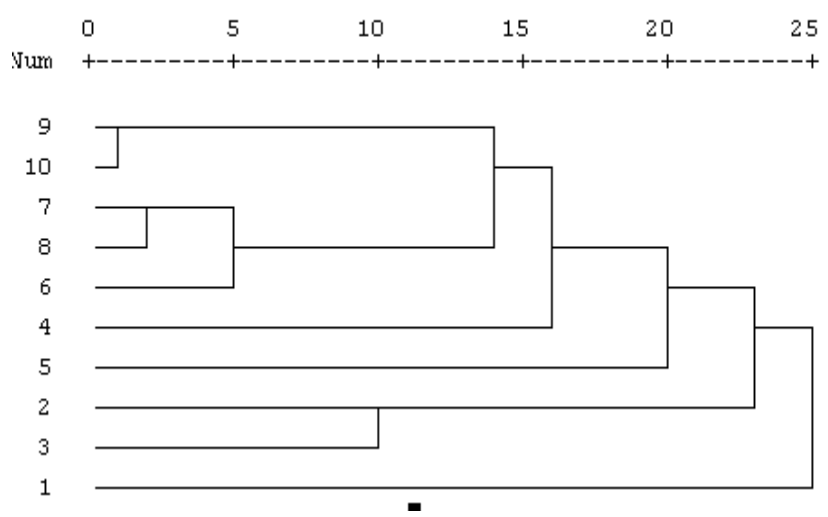

Figure (2): Dendrogram of the genetic distances among the ten faba bean genotypes based on ISSR analysis. 


\section{REFERENSES}

Abdel-Razzak H. S.; A. M. Alfrmawy; H. M. Ibrahim and A. El-Hanafy (2012). Genetic Diversity in Faba Bean (Vicia faba L.) Using Inter-Simple Sequence Repeat (ISSR) Markers and Protein Analysis. Life Sci J; 9(2):497-503].)

Al Barri, T. H. M. and J. Y. S. Munqez (2013). Phenotypic characterization of faba bean (Vicia faba L.) Landraces grown in Palestine. J. of Agric. Sci., 5(2) 110-117.

Ashok S. Sajjan; N. D. Prashanth and R. M. Hosmani (2008). RAPD markers and morphological characteristics for identification of french bean (Phaseoous vulgaris L.) cultivars. Seed Res., 36 (1): 81-83.

Belaj, A.; Z.Satovic; G.Cipriani; L.Baldoni; R.Testolin; L. Rallo and I. Trujillo (2003): Comparative study of the discriminating capacity of RAPD, AFLP and ISSR markers and of their effectiveness inestablishing genetic relationships in olive. Theoretical and Applied Genetics, 107: 736-744.

Bhagyawant ,S.S and N. Srivastava (2008). Genetic fingerprinting of chickpea (Cicer arietinum L.) germplasm using ISSR markers and their relationships. Afr J Biotechnol, 7: 4428-4431.

Bonetti, A.; A. Miggiano; G. Dinelli and A. Lovato (1995). Identification of bean (Phaseolus vulgaris L.) cultivars grown in Italy by field and electrophoresis tests: a comparative study. Seed Sci. Tech., 23: 69- 84.

Chen, Y.; R. Zhou; X. Lin; K. Wu; X. Qian and S. Huang (2008). ISSR analysis of genetic diversity in sacred lotus cultivars. Aquatic Botany 89: 311-316.

Chowdhrury. M. A.; B. Vandenberg and T. anrkentin (2002). Cultivar indentification and genetic relationship among selected breeding lines and cultivars in chickpea (Cicer arietinum L. ). Euphytica, 127: 317325.

Duc, G; S. Bao; M. Baum; B. Redden; M. Sadiki; M. JSuso; M. Vishniakova and X. Zong (2010). Diversity maintenance and use of Vicia faba $L$. genetic resources. Field Crops Research, 115: 270-278.

Galvain M. Z.; B. Bornet; P. A. Balatti and M. Branchard (2003). Inter simple sequence repeat (ISSR) markers as a tool for the assessment of both genetic diversity and gene pool origin in common bean ( Phaseolus vulgaris L.). Euphytica, 132: 297-301.

Gomez, K. A. and A. A. Gomez (1984). Statistical Procedures for the Agricultural Researchers. John wiley and Sons. Inc, New York.

IBPGR (1984). International Board of Plant Genetic Resources. Crop Genetic Resources, PP. 19-22, Rome.

Ibrahim, H. M. (2010). Heterosis, combining ability and components of genetic variance in faba bean (Vicia faba L.). Arid Land Agric. Sci., 21 (1): 35-50. 
Jabbarzadeh, Z.; M. Khosh-khui; H. Salehi and A. Saberivand (2010). Inter simple sequence repeat (ISSR) markers as reproducible and specific tools for genetic diversity analysis of rose species. African J. of Biotech., 9(37): 6091-6095.

Lalazar, S. (2012). Evaluation of yield stability of beans genotypes in diffirent environment conditions. Intern. J. of Agron. and Plant Production, 3 (10), 356-360.

Link, W.; C. Dixkens; M. Singh; M. Schwall and A. Melchinger (1995). Genetic diversity in European and Mediterranean faba bean germplasm revealed by RAPD markers. Theoretical and Applied Genetics, 90: 27-32.

Mudzana, G.; A. A. Pickett; R. J. Jarman and R. J. Cooke (1995). Variety discrimination in faba beans: an integrated approach. Plant Verities and Seed, 8: 135-45.

Parsons, B. J.; H. J. Newbury; M. T. Jackson and B. V. Ford-Lloyd (1997). Contrasting genetic diversity relationships are revealed in rice (Oryza sativa L.) using different marker types. Molecular Breeding, 3: 115-125.

Pezzotti, M.; C. Tomassini; M. Falcinelli and F. Veronesi. (1994). Evaluation of an Italian germplasm collection of Dactylis glomerata L. using a multivariate approach. J. Gene \& Breed., 48: 17-24.

Pharmawati M.; G. Yan and P. M. Finnegan (2005). Molecular variation and fingerprinting of Leucadendron cultivars (Proteaceae) by ISSR markers, Ann. Bot., 95: 1163-1170.

Rehab, T. B. (2007). Identification of some broad bean ( VICIA FABA L.) varieties using morphological, chemical and biotechnological techniques. Ph. D. Thesis, Fac. of Agric. Moshtohor Univ., Egypt.

Salem, S.; A. Alghamdi; C. A. Sulieman; A. Al-Faifi; M. Hussein, A. Migdadi; H. Megahed; A. Ammar and K. H. M. Siddique (2011). Inter-simple sequence repeat (ISSR)-based diversity assessment among faba bean genotypes Crop and Pasture Science, 62(9) 755-760

Sambrook, J.; E. F. Fritsch and T. Maniatis (1989). Molecular Cloning. A Laboratory manual, Second Edition. Volume 1.

UPOV (2002). The International Union for the Protection of New Varieties of plants. Guidelines for the conduct of tests for distinctness, uniformity and stability for canola descriptor No. TG/36/6.

Zeid, M.; S. Mitchell; W. Link; M. Carter; A. Nawar; T. Fulton and S. Kresovich (2009). Simple sequence repeats (SSRs) in faba bean: new loci from Orbanche-resistant cultivar 'Giza 402'. Plant breeding 128(2): 149-155.

Zubair M.; U. A. Saif; A. Muhammad and A. M. Haqqani (2007). Multivariate analysis quantitative traits in mungbean (VIGNA RADIATA L.) wilczek. Pac. J. Bot, 39(1): 103-113. 


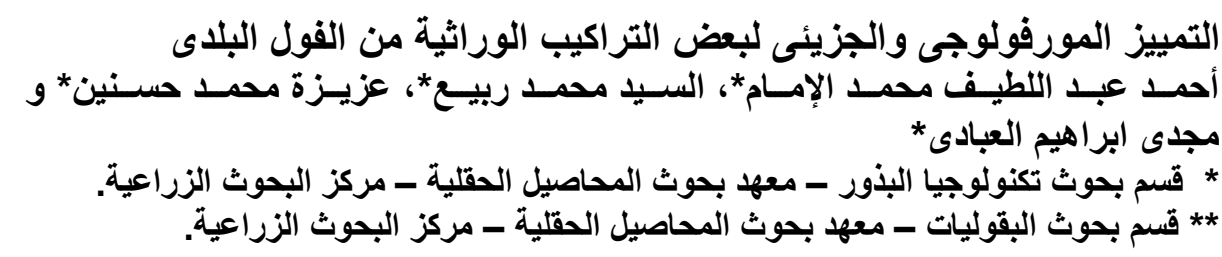

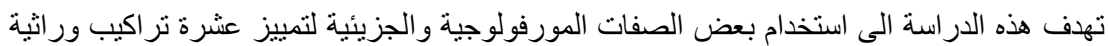

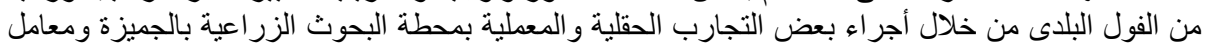

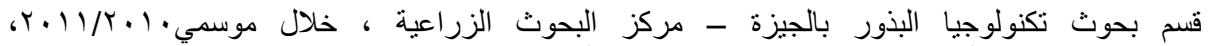

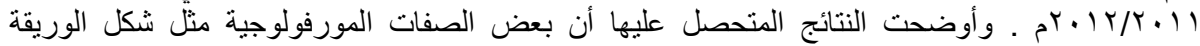

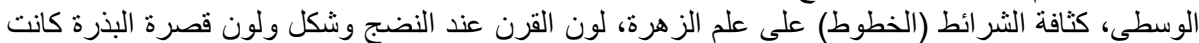

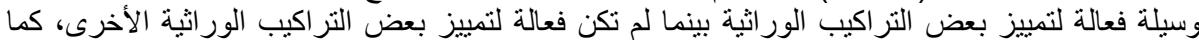

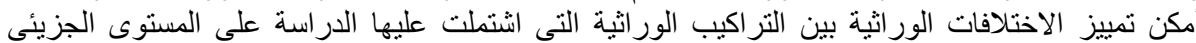

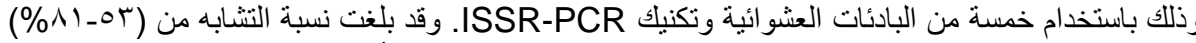

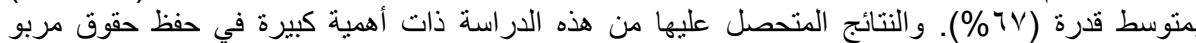

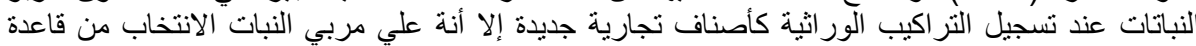

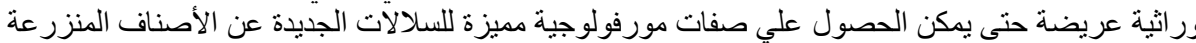
المسجلة وذلك عند تسجيلها كأصناف جديدة مما يسهل التحقق من نقاوة الصنف الجديد أنثاء مراحل الأنثارة

المختلفة. 